\title{
Does Ramadhan affect abnormal return?
}

\author{
I. Ashari \& Y. Soesetio* \\ Universitas Negeri Malang, Malang, Indonesia
}

\begin{abstract}
This study aimed to test the stock performance during the month of Ramadhan and other Hijriah months in 1432-1438 H. A comparative study with a quantitative approach to the selected sample data of 16 issuers who are members of the SRI-KEHATI index were used. This study employed a paired sample t-test. The analysis indicated that there are differences in stock abnormal returns each month, but this does not prove that the Ramadhan month effect anomaly always occurs. Interestingly, this study proves that, when Ramadhan month arrives, it is suspected that investor behavior tends to avoid risk, since existing beliefs and rumors influence investor behavior in Indonesia.
\end{abstract}

Keywords: abnormal return, Hijriah, Ramadhan, SRI-Kehati Index

\section{INTRODUCTION}

The efficient market hypothesis (EMH) is an ideal framework and is expected to occur in the capital market. Suppose the market reacts quickly and accurately to any information that occurs and immediately forms a new equilibrium price. In that case, investors will find it difficult to obtain a profit level above normal (abnormal return). Fama (1970) divided the efficient market into three forms: the weak-form efficient market, the semi-strong form efficient market, and the strong form efficient market. One form that is often debated and anomalous is the weak form of an efficient market. Market anomalies are observations that cannot be explained by EMH assumptions and cannot be explained by logic (Oncu et al. 2017).

The various forms of weak market anomalies known so far are the Holiday effect, Day of the week, Monday Effect, Weekend effect, Monthly effect, etc. One of the events of the Monthly effect that causes abnormal returns and is still interesting to study is the effect of the month of Ramadhan (Ramadhan effect). The month of Ramadhan is one of the holy months for Muslims, which demands that every Muslim be prohibited from eating and drinking, and having husband and wife relations during the day from dawn to dusk. This is thought to make people's daily life patterns, especially Muslims, change during the month of Ramadhan and other months. Every devout Muslim will carry out more and more quality religious activities such as increasing sunnah prayers, i'tikaf, reading the Al-Quran, infaq, and shodaqoh (Tan \& Ozlem 2018). However, just before Idul Fitri, people will buy more needs than usual (zakat, clothes, food, homecoming costs, etc.). This has led to the high level of public consumption during the month of Ramadhan. On the eve of Eid al-Fitr in 2013, household consumption even reached IDR 110 trillion or nearly $10 \%$ of the total State Budget (APBN), so that the 2013 changes reached IDR 1,683 trillion (Utomo \& Herlambang 2015).

During the month of Ramadhan, the high level of public consumption during the month of Ramadhan is thought to have caused consumption or transactions on the stock market to decline or people to pay less attention to investing in the stock market. Mustafa (2011) examined the effects of the month of Ramadhan using the KSE-100 index on the Karachi Stock Exchange with

\footnotetext{
${ }^{*}$ Corresponding author
} 
the research period December 1991 to December 2010. He found that the average return during Ramadhan is lower and significant, which means the Ramadhan effect is present on the stock exchange Karachi. Another study conducted by Utomo and Herlambang (2015) examined the of Eid holidays on average abnormal returns and found that the significant average abnormal return was in the period before the Eid al-Fitr holiday (Ramadhan), both positive and negative. Munusamy (2018) investigated the Islamic calendar effect on the returns of the Shariah and common indices in India. The data include the daily values of the BSE Sensex, Nifty 50, Nifty Shariah, Nifty Shariah 500, and MSCI over the period from January 4, 2010, to March 31, 2016, and found that the average returns of the stock markets are higher during the Ramadhan days than non-Ramadhan days over the study period.

Meanwhile, previous research conducted by Seyyed et al. (2005) on the phenomenon of the Muslim month, namely the month of Ramadhan on the Saudi Equity Market (the largest equity market in the Middle East and the Islamic world) shows that the average rate of return is not affected by the events of the month of Ramadhan. there is even a significant decrease in volatility, which indicates a predictable change in price and results in fewer transactions during the holy month. Then Shah et al. (2014) conducted a study using daily data on the KSE 100 index. From January 1, 2010 to December 31, 2012, the study found that religious factors are not related to financial markets. Markets remain the same during the month of Ramadhan similar to the other months.

This study was conducted to examine the effect of the month of Ramadhan (Ramadhan effect), which is compared with other months by comparing the CAAR value indicator (Cumulative Average Abnormal Return). This study employed shares incorporated in the SRI-KEHATI index, a collection of 25 leading stocks based on an assessment of the implementation of Sustainable and Responsible Investment (SRI) corporate management procedures. This study was conducted in 1432-1438 H (7 December 2010 - 20 September 2017).

\section{LITERATURE REVIEW}

\subsection{The cumulative average abnormal return}

Abnormal return is also a form of market reaction to an announcement that contains information. The abnormal return is the advantage of the return that occurs against the normal return (Hartono 2012). Positive abnormal returns identify that the actual stock return during the event period is greater in value than investors' expectations. Negative abnormal returns identify that the actual return in stocks during the event period is smaller than investors' expectations.

This study used a market-adjusted model or a market-adjusted model, assuming that the best predictor for estimating a security return is the market index at that time (Hartono 2012). The formula used to calculate the cumulative average abnormal return is as follows (1).

$$
C A A R_{t}=\frac{\sum C A R_{i t}}{k}
$$

where $\mathrm{CAAR}_{\mathrm{t}}=$ cumulative average abnormal return of all samples in period $\mathrm{t} ; \mathrm{CAR}_{\mathrm{it}}=$ cumulative abnormal return shares me in period $\mathrm{t}$; and $\mathrm{k}=$ number of samples.

\subsection{Efficient market}

Stock markets offer a platform where shares can be valued efficiently (Toit \& Hall 2018). Fama (1970) defines the financial market as efficient if the price offered always reflects the information available. According to $\mathrm{EMH}$, the stock price changes randomly where the price at the future is unpredictable. If there is new information, the information appears randomly so that price changes to the information cannot be predicted. EMH is a trading situation in the capital market that shows the relationship between market prices and market forms. The market price is determined by the capital market mechanism, or in other words formed by how much influence the relevant information considered in making investment decisions (Sunariyah 2011). 


\subsection{Capital market anomalies}

Anomaly is a generic term in nature. It applies to any fundamental novelty of fact, new and unexpected phenomenon or a surprise about any theory, model, or hypothesis (Latif et al. 2011). An efficient market reports stock prices that fully reflect available information and maintain the return-risk relationship (Hamid et al. 2010; Latif et al. 2011; Toit et al. 2018). However, suppose there is any pattern in share price movements. In that case, it shows that the market is inefficient, and that market anomaly can be exploited to the advantage of investors (Toit \& Hall 2018).

Capital market anomaly means a situation in which stock performance or a group of stocks deviates from the assumptions of efficient market hypotheses. Such movements or events that cannot be explained using efficient market hypotheses are called financial market anomalies (Latif et al. 2011). Anomalies in the capital market are divided into four types: company anomalies, seasonal anomalies, event anomalies, and accounting anomalies.

\subsection{Ramadhan effect}

The average stock return tendency on the day before the holiday (pre-holiday return) is higher. The average stock return on the day after the holiday (post-holiday return) is lower, compared to the normal daily rate return or the Holiday effect. The holiday effect in capital market activities on the Indonesia Stock Exchange (IDX) has several holidays, for example, the religious holiday effect, where Indonesia has the largest Muslim majority in the world, and every year the Muslim community always holds a religious festival, namely with the arrival of the month of Ramadhan (Ramadhan effect) which is followed by the Idul Fitri holiday.

Al-Ississ (2010) stated that there are two reasons when the equity market is affected by culture and religious festivals. First, on days of religious and cultural festivals, followers of certain religions do not enter the stock market. Their absence can have a one-sided effect if they are all absent at the same time while the attitude towards investment decisions or have no effect if they differ from the investment point of view. Second, investor mood is a function of religious events that influence investment deci sions or investor overreaction behavior towards current information. This condition is also inseparable from psychological factors because psychologically, investors will react more dramatically to insufficient information.

The investor's perspective tends to be more sensitive to differences in months and specific moments. Thus making people more sensitive emotionally to the impact of external influences. Islamic religious warnings such as Ramadhan and Idul Fitri affect the behavior of the stock market.

Thus, it will cause economic activity to slow down because at that moment, investors will have the opportunity to get the chance to get an abnormal return compared to other months.

\subsection{Financial behavior}

Financial behavior is the study of the influence of psychology on financial practitioners' behavior and the subsequent effect on markets. Behavioral finance is of interest because it helps explain why and how markets might be inefficient (Sewell 2010). Studying, financial behavior must understand the concepts of psychology, sociology, and finance to know the whole idea of economic action. Financial behavior tries to explain and improve investor patterns, including emotional processes and influences in making decisions. Financial behavior also tries to explain what, why, and how finance and investments are based on the human perspective. For example, financial behavior studies financial markets where many market anomalies occur such as the January Effect, speculative market bubbles, and crashes (for example in 1929 and 1987) (Pratama \& Wijaya 2020).

\section{METHODS}

This study was conducted using a comparative model, which is used to compare or describe the differences caused by certain events. The situation during religious events, especially the 
month of Ramadhan (Ramadhan effect) is an event in this study, which observes stock price movements, especially on the SRI-Kehati index, to determine whether there is a difference in the cumulative average abnormal return during Ramadhan with months other than Ramadhan, namely Muharram, Safar, Rabiul Awal, Rabiul Akhir, Jumadil Awal, Jumadil Akhir, Rajab, Sya 'ban, Syawal, Dzulkaidah, and Dzulhijjah. The period in this study used the Hijri year, namely 1432-1438 H (7 December 2010-20 September 2017). The reason for choosing a period is that the longer the research period, the better it is in predicting research results, both in terms of mood and the psychology of investors. The population used is all issuers that are members of the SRI-Kehati Index, namely 25 companies. The sample was selected based on specific criteria or purposive sampling by the research plan, namely being continuously incorporated in the SRI-Kehati index and found as many as 16 companies during the observation period of 1432-1438 H (7 December 2010-20 September 2017), and had data complete.

\section{RESULTS AND DISCUSSION}

This study captures an overview of the abnormal return conditions in each month of Hijriah calendar. The average abnormal return in this study illustrates that the movement of the average cumulative abnormal return of stocks has increased and decreased every month or, in other words, fluctuated.

The highest cumulative average abnormal return in Rabiul Akhir was 0.0214 , which means that in the month of Rabiul Akhir, the issuers who are members of the SRI-Kehati index will benefit from their investment returns, such as the closing price of ASII (Astra International) in Rabiul Akhir. The end of February 9 2015, to be precise, increased from 7,575 to 7,950 to 12 February 2015 (Bursa Efek Indonesia, 2015); on the other hand, the lowest cumulative average abnormal return was in the month of Rajab, which was -0.0060 , which means that the SRI-Kehati Index issuers have suffered losses on investment returns. Then, if an outline is drawn, the abnormal return movement of the SRI-Kehati index in the observation period appears to be moving downhill.

Table 1 shows the average CAAR value and the results of the CAAR difference test, which in the month of Ramadhan has the second-lowest average CAAR after the month of Rajab. For the different test results presented in Table 1, the CAAR difference test between Ramadhan and month Rabiul Awal and Dzulkaidah produced a significance value of less than 0.05 , which means that there is a difference between the CAAR of the month of Ramadhan and the months of Rabiul Awal and Dzulkaidah. While the $t$ value produces a negative value, the CAAR value in the month of Ramadhan is lower than the months of Rabiul Awal and Dzulkaidah. Whereas for other months apart from Rabiul Awal and Dzulkaidah there is no significant difference in CAAR.

Table 1. Paired sample t-test hypothesis test results.

\begin{tabular}{llllll}
\hline Period & $\begin{array}{l}\text { Mean } \\
\text { Ramadhan }\end{array}$ & Others & $\mathrm{t}$ & Sig (2 Tailed) & Conclusion \\
& & & & \\
\hline Ramadhan - Muharram & -0.0051 & -0.0005 & -0.487 & 0.643 & Not significant \\
Ramadhan - Safar & -0.0051 & 0.0075 & -2.073 & 0.084 & Not significant \\
Ramadhan - Rabiul Awal & -0.0051 & 0.0148 & -5.671 & 0.001 & Significant \\
Ramadhan - Rabiul Akhir & -0.0051 & 0.0214 & -1.858 & 0.112 & Not significant \\
Ramadhan - Jumadil Awal & -0.0051 & 0.0108 & -1.778 & 0.126 & Not significant \\
Ramadhan - Jumadil Akhir & -0.0051 & -0.0022 & -0.337 & 0.748 & Not significant \\
Ramadhan - Rajab & -0.0051 & -0.0060 & 0.087 & 0.933 & Not significant \\
Ramadhan - Sha'ban & -0.0051 & -0.0037 & -0.143 & 0.891 & Not significant \\
Ramadhan - Shawwal & -0.0051 & 0.0048 & -0.694 & 0.514 & Not significant \\
Ramadhan - Dzulkaidah & -0.0051 & 0.0092 & -2.494 & 0.047 & Significant \\
Ramadhan - Dzulhijjah & -0.0051 & -0.0004 & -0.831 & 0.438 & Not significant \\
\hline
\end{tabular}


In this study, most observations on Ramadhan events occurred during July. May until July is the most of the month of dividend distribution. At the Ramadhan period, the average return was significantly higher and lower depending on the month the Ramadhan occurred (Rokhim 2019). The Ramadhan effect phenomenon does not happen in Indonesia, especially on the BEI compared to other countries, allegedly due to cultural differences and different conditions during the month of Ramadhan between Indonesia and other countries (Rusmayanti et al. 2016). This study's results support the research made by Mustafa (2011) on the effects of Ramadhan on the Karachi Stock Exchange - 100 for the period of December 1991 - December 2010. In his research, it was found that the average return in Ramadhan is lower and significant. However, there is a positive and significant average return found in the months of Shawwal and Dzulkaidah. There are two reasons when the equity market is affected by culture and religious festivals. First, on days of religious and cultural festivals, certain religions' followers do not enter the stock market. The impact of their absence can cause one-sided effects if they all have the same attitude towards investment decisions or can have no impact if opinions differ. Second, investor mood is a function of religious events that influence investment decisions or investor overreaction behavior towards current information (Al-Ississ 2010).

The month of Rabiul Awal in the observation period of this research, when converted into Masehi, will be in December to March with the January period being the majority period of observation as many as 5 periods. It is suspected that during this period, the January effect was in effect, which was an abnormal return that was higher than other months. At the end of the year, there were many stock sales to reduce taxes (tax-loss selling). Investors sold securities that had suffered a loss before the end of the year and would buy back the securities. The act of selling at the end of December and buying in early January causes a decline in prices at the end of the year and an increase at the beginning of the year (Pradnyaparamita \& Rahyuda 2017). With such data collected, it is strongly suspected to be the cause of differences in performance.

This strategy is generally carried out by buying leading stocks that drive the index. It is better to buy stocks that are small in number but have a large portion (influence) of the IHSG than stocks that are large in number but have small influence. This is the aim of enhancing performance is used to rearrange the portfolio in a number of periods. This is followed by profit-taking by selling superior stocks that have risen in price and then exchanging them with second-tier stocks as well as taking advantage of the early moments of the year to become an event for investors to start trading enthusiastically as in the beginning of every activity that always looks high in enthusiasm but cannot be maintained in the next period.

Meanwhile, most of the month of Dzulkaidah in this study is September. This period coincides with the third quarter of the company's performance, which means that its version has been running for several quarters of the work period. The remaining period has less impact. Based on this, fund managers and investors can predict the company's performance in the current year and begin to prepare the selection of leading stocks to own and second-tier stocks in anticipation to be selected and used for the window dressing and January effect periods. By taking advantage of information asymmetry between traders, it will make players who have fundamental information, especially private information, which is formed, one of which is with trading experience so far, to get returns. In fact, in Dzulkaidah or September, the total average value of trading volume is 0.00232 or $34,407,916$ (researchers process the data), so that in the month of Dzulkaidah the tendency of investors and traders to get returns (Siaputra 2006). Thus, it can be concluded that there is a difference between the abnormal return before the event which tends to decrease and the abnormal return after, which tends to increase.

\section{CONCLUSION}

It is not statistically proven that there is a significant CAAR anomaly in the month of Ramadhan with other months other than the month of Rabiul Awal and Dzulkaidah in companies listed in the SRI-KEHATI Index. This is presumably because most people or investors do not use the 
Islamic calendar as the main reference for determining when to invest. However, it is assumed that during Ramadhan, investors prefer to use their funds to meet consumption needs and the effects of inflation. The enactment of the January effect is an anomaly return that is higher than in other months. At the end of the year, many fund managers and investors repair and rearrange portfolios by selling stocks to reduce taxes (tax-loss selling), reducing stock portfolio losses before the end of the year, and at the beginning of the year will buy back securities. Meanwhile, during the month of Dzulkaidah, which coincides with the period from September to October, the period for information on the distribution of interim dividends occurs. As a result, unconsciously investors and traders will overestimate the opportunity for an abnormal return to coincide with the month of Dzulkaidah. Thus, it should be assumed that Indonesia's investors when making decisions are dominated by psychological aspects, moods, and habits.

\section{REFERENCES}

Al-Ississ, M. 2010. The impact of religious experience on financial markets. Working Paper. Harvard Kennedy School of Government.

Bursa Efek Indonesia. 2015. Ringkasan saham. 02 December 2020. https://idx.co.id/data-pasar/ringkasanperdagangan/ringkasan-saham/.

Fama, E. F. 1970. Efficient capital markets: a review of theory and empirical work. The Journal of Finance 25(2).

Hartono, J. 2012. Pasar efisien secara informasi, operasional dan keputusan. Yogyakarta: BPFE-Yogyakarta.

Latif, M., et al. 2011. Market efficiency, market anomalies, causes, evidences, and some behavioral aspects of market anomalies. Research Journal of Finance and Accounting 2(9).

Munusamy, D. 2018. Islamic calendar and stock market behaviour in India. International Journal of Social Economics 45(11): 1550-1566.

Mustafa, K. 2011. The islamic calendar effect on karachi stock market. Global Business Review 13(3): 562-574.

Oncu, M. A., Unal, A. \& Demirel O. 2017. The day of the week effect in borsa istanbul: a garch model analysis. International Journal of Management Economics and Business 13(3): 521-534.

Pradnyaparamita, N. M. W., Rahyuda, H. 2017. Pengujian anomali pasar january effect pada perusahaan LQ45 di bursa efek Indonesia. E-Jurnal Manajemen Unud 6(7): 3513-3539.

Pratama, A. \& Wijaya, C. 2020. The impact of Ramadhan effect on abnormal return. SSRG International Journal of Economics and Management Studies 7(4): 213-221.

Rokhim, R. \& Octaviani, I. 2019. Is there a Ramadhan effect on Sharia mutual funds? Evidence from Indonesia and Malaysia. International Journal of Islamic and Middle Eastern Finance and Management 13(1): $135-146$.

Rusmayanti, A., Yusniar, M. W., Juniar, A. 2016. Pengaruh bulan Ramadhan terhadap return pasar saham di bursa efek Indonesia (1425 H-1434 H). Jurnal Wawasan Manajemen 4(1).

Seyyed, F. J. Abraham, A. Al-Hajji, M. 2005. Seasonality in stock returns and volatility: the Ramadhan effect. Research in International Business and Finance 19(3): 374-383.

Sewell, M. (2010). Behavioural finance. University of Cambridge.

Siaputra, L., Atmadja, A. S. 2006. Pengaruh pengumuman dividen terhadap perubahan harga saham sebelum dan sesudah ex-dividend date di bursa efek Jakarta (BEJ). Jurnal Akuntansi dan Keuangan 8(1).

Shah, S. M., Atiq U. R., Syed N. A. 2014. The Ramadhan effect on stock market. European Academic Research 1(11): 4712-4720.

Sunariyah. 2011. Pengantar pengetahuan pasar modal edisi keenam. Yogyakarta: UPP STIM YKPN.

Tan, O. F. \& Ozlem, S. 2018. Ramadhan effect on stock markets. Journal of Research in Business 3(1): 77-98.

Toit, E. D., Hall, J. H., Pradhan, R. P. 2018. The day-of-the-week effect: South African stock market indices. African Journal of Economic and Management Studies 9(2): 197-212.

Utomo, V. J. \& Herlambang, L. 2015. Efek hari libur lebaran pada emiten yang terdaftar dalam ISSI periode 2011-2013. Jurnal Ekonomi Syariah Teori dan Terapan (JESTT) 2(5). 